\title{
Suppression of grasshoppers in the Great Plains through grazing management
}

\author{
JEROME A. ONSAGER
}

Author is research entomologist (retired), USDA/ARS, Northern Plains Agricultural Research Laboratory, Sidney, Mont. 59270. Current address is 4141 Blackwood Road, Bozeman, Mont. 59718.

\section{Abstract}

It was hypothesized that grazing management could mitigate grasshopper outbreaks on native rangeland in the northern Great Plains. Key practices would require deliberate variation in timing and intensity of grazing events, preservation of canopy during critical periods of grasshopper development, and reductions in areas of bare soil. The twice-over rotational grazing system appeared compatible with those requirements.

Grasshopper population trends were monitored during 1993-1995 and 1997-1998 on commercial native rangeland under twice-over rotational grazing vs traditional season-long grazing. A ubiquitous pest grasshopper, Melanoplus sanguinipes (Fabricius), occurred at every sample site during each year in numbers sufficient to provide life history parameters for comparison between treatments. Under rotational grazing, the nymphs developed significantly slower and their stage-specific survival rates were significantly lower and less variable. Consequently, significantly fewer adults were produced significantly later in the season under rotational grazing.

Seasonal presence of all grasshopper species combined averaged 3.3X higher under season-long grazing than under rotational grazing. Local outbreaks that generated 18 and 27 adult grasshoppers per $\mathrm{m}^{2}$ under season-long grazing in 1997 and 1998, respectively, did not occur under rotational grazing. The outbreaks consumed $91 \%$ and $168 \%$, respectively, as much forage as had been allocated for livestock, as opposed to $10 \%$ and $\mathbf{2 3 \%}$, respectively, under rotational grazing.

Of 9 important grasshopper species, none were significantly more abundant at rotational sites than at season-long sites. Three species that were primary contributors to outbreaks under season-long grazing remained innocuous under rotational grazing. It therefore appears that outbreak suppression through grazing management is feasible in the northern Great Plains.

Key Words: grasshopper management, twice-over grazing system, rotational grazing, Melanoplus sanguinipes

In a study of statistical density dependence among rangeland grasshoppers in Montana, Kemp and Dennis (1993) reported equilibrium or "return tendency" parameters for populations in 3 regions of the state; northern plains, southern plains, and western mountains. Long-term median $\left(5.3,5.4,4.8 \mathrm{~m}^{-2}\right)$ and mean $(6.1$, $6.2,6.3 \mathrm{~m}^{-2}$ ) densities of adult grasshoppers were similar for the

The author acknowledges Selene Gaffri, Kathy Johnson, Gerald Mussgnug, and Jeffrey Holmes for technical assistance.

Manuscript accepted 17 Feb. 2000.

\section{Resumen}

Hipotetizamos que el manejo del apacentamiento podráa mitigar los brotes de chapulines en los pastizales de las Grandes Planices del Norte. Practicas clave podráan requerir la variación deliberada en tiempo e intensidad de los eventos de apacentamiento, la preservación de la copa durante los periodos cráticos del desarrollo de los chapulines y la reducción de áeas de suelo desnudo. El sistema rotacional doble parece ser compatible con esos requerimientos.

Las tendencias de la población de chapulines se monitorearon de 1993 a 1995 y de 1997 a 1998 en pastizales nativos comerciales manejados bajo los sistemas de apacentamiento rotacional doble rotación y el sistema tradicional de apacentamiento estacional. En todos los sitos experimentales cada año se tuvo plaga de chapulines [Melanoplus sanguinipes (Fabricius)] en numero suficiente para proveer los par-metros del historial de vida utilizados para comparar los tratamientos. Bajo el sistema de apacentamiento rotacional el desarrollo de las ninfas fue significativamente mas lento y las tasas de sobrevivencia en estados especáficos fueron significativamente menores y menos variables. Consecuentemente, con el sistema rotacional la producción de adultos fue significativamente mas baja y los adultos se produjeron significativamente mas tarde.

La presencia estacional de la combinación de todas las especies de chapulines promedio 3.3 veces mas en el sistema de apacentamiento estacional que en el rotacional. Los brotes locales de1997 y 1998 produjeron 18 y 27 chapulines adultos por m ${ }^{2}$ bajo el sistema estacional y estos brotes no ocurrieron con el sistema de apacentamiento rotacional. Los brotes de chapulines consumieron el 91 y $168 \%$ del forraje que habáa sido asignado para el ganado, en tanto que en el sistema rotacional el consumo fue del 10 y $23 \%$ respectivamente.

De 9 especies importantes de chapulines ninguna fue significativamente mas abundante que otra en ambos sistemas de apacentamiento. Tres especies que fueron las principales en los brotes ocurridos en el sistema estacional permanecieron inocuas bajo el sistema rotacional. Por lo tanto, parece que en la región de las Grandes Planicies del Norte la supresión de brotes de chapulines es factible mediante el manejo del apacentamiento.

respective regions. However, estimated regional carrying capacities were much higher for the 2 plains regions than for the mountains ( 8.9 and 8.6 vs $6.3 \mathrm{~m}^{-2}$, respectively). Consequently, grasshopper populations were much more variable in the plains, and grossly over-shot the carrying capacity (i.e., reached outbreak levels) much more frequently than in the mountains. These results provided useful insights for assessing opportunities for 
long-term grasshopper management in the northern Great Plains.

Whether ranch managers realize it or not, the effects of long-term mean or median grasshopper populations have been factored into historical livestock carrying capacities in the northern Great Plains. Total forage consumption by grasshoppers plus livestock usually does not exceed intended levels, but grasshoppers far exceed normal consumption during outbreaks. Therefore, a goal of grasshopper management could be to reduce either the frequency, the severity, or the duration of an outbreak. A viable approach might be to reduce grasshopper carrying capacity by making the rangeland environment less hospitable for these pests.

\section{Grazing Management and Grasshopper Outbreaks}

In several Great Plains ecosystems, grasshoppers tend to achieve highest densities in the presence of grazing during years of low precipitation and low forage production. Grasshoppers have been reported to be unusually abundant during dry seasons in heavily grazed pastures of mixed grass prairie in Oklahoma (Smith 1940), tall grass prairie in Kansas (Campbell et al. 1974), unspecified habitat in eastern Montana (Pepper 1955), and fescue grassland in Alberta (Holmes et al. 1979). In eastern Montana, grasshopper populations were inversely proportional to plant canopy height, and highest infestations occurred where ground cover was less than 40\% (Anderson 1964). These reports provided primarily qualitative descriptions of relationships, but some quantification can be extracted from other data for Montana. Kemp (1992) reported long-term grasshopper density data for eastern Montana rangeland, and Kemp and Cigliano (1994) reported long-term drought index data for the same region. During 19 seasons for which data on both variables were available, above-average grasshopper densities occurred 1 year out of 8 in the absence of drought, but occurred 7 years out of 11 in the presence of drought. Thus, there is little doubt that the greatest demand for available forage in eastern Montana occurred during seasons when ranchers could least afford to feed grasshoppers.

A modeling exercise by Onsager (1983) suggested that density levels and forage destruction rates by the migratory grasshopper, Melanoplus sanguinipes (Fabricius), were most sensitive to changes in survival rate and development rate. In field tests, Grant et al. (1993) determined that rates of mortality, nymphal development, and egg production were, in that order, the 3 most important determinants of population fitness. Thus, successful management would likely have to impair at least one of those functions.

In a discussion of potential tactics for proactive grasshopper management, Onsager (1995) dismissed traditional season-long grazing as offering little opportunity. Periodic grasshopper outbreaks of the past have occurred predominantly under season-long grazing, and the species involved are now cited as classic examples of obnoxious pests. In contrast to seasonlong grazing, deferment or rotation of grazing periods can deliberately manipulate the time, rate, or degree of defoliation, which in turn might be strategically useful in influencing the time, rate, degree, or direction of change in habitat for grasshoppers. The latter strategies also may prevent repetitively favoring the same pest species in the same pasture for consecutive seasons.

Anderson's (1964) report of high infestations associated with low ground cover also provided a useful, testable hypothesis. Two pest species ranked among the 5 worst by Dysart (1995), Aulocara elliotti (Thomas) and Ageneotettix deorum (Scudder), are known to deposit their eggpods horizontally in small patches of bare soil, just below the surface (Anderson and Hastings 1966, Onsager 1963), where heat accumulation is maximized (Pierson and Wight 1991). This promotes a well-synchronized hatch that is completed relatively early in the season (Fisher 1994), and the young nymphs accommodate relatively cool temperatures by basking in the bare patches with their bodies perpendicular to sunlight and in contact with the warm soil. Reducing the size and frequency of bare spots should reduce densities of those 2 species and perhaps slow down the development rate of other species as well.

Consolidation of the preceding considerations yielded 3 hypothetical attributes of a grazing system that might deter (or, at least, fail to encourage) grasshopper outbreaks in the northern Great Plains. These were; (1) deliberate variation from year to year in the time and intensity of defoliation periods, (2) controllable preservation or enhancement of shading canopy during critical portions of grasshopper life cycles, and (3) reduction or elimination of bare soil. The twice-over rotational grazing system appeared to be compatible with those requirements.
The twice-over rotational grazing strategy was described in detail by Manske (1994a) and Biondini and Manske (1996). From the perspective of hypothetical beneficial attributes for grasshopper management, it can be described briefly as follows. It requires 2 sequential rotations of a herd of livestock through a series of 3 to 6 pastures within a 4.5-month grazing season. In the northern Great Plains, the first grazing cycle occurs 1 June to 15 July. This grazing cycle tends to distribute defoliation over a higher proportion of plants and tends to leave a more level canopy than typically occurs when the herd has continuous access to the same total area during the same period of time. During the interval between the 2 grazing periods within each pasture, new tillers proliferate and tend to fill in the bare spots. The canopy produces relatively few reproductive stems, so it tends to remain relatively level while it grows in height. The second grazing cycle occurs 16 July to 15 October, when pastures are grazed for a second time, in the same sequence as for the first time, for twice as many days as they were grazed during the first cycle. The second cycle also appears to promote more uniform harvest than typically seen under season-long grazing. That may have an important impact on soil temperatures, grasshopper basking efficiency, and grasshopper egg development rates, because less soil is exposed to direct sunlight for a shorter time than under seasonlong grazing. The exit pasture becomes the entry pasture for the next season, but otherwise the same sequence of pasture use is retained from year to year, which assures that periods of pasture usage are systematically changed each year. That could reduce the probability that any given pest grasshopper species will be inadvertently favored for successive generations in any given pasture.

\section{Materials and Methods}

\section{The Study Area}

The experimental area was $34 \mathrm{~km}$ west of Watford City, N.D., between $47^{\circ} 35^{\prime}$ to $47^{\circ} 50^{\prime} \mathrm{N}$ Lat and $104^{\circ} 00^{\prime}$ to $103^{\circ} 45^{\prime} \mathrm{W}$ Long, within the McKenzie County Grazing District of the Little Missouri National Grasslands. The forage base is predominantly native prairie comprised of blue grama [Bouteloua gracilis (HBK.) Lag. ex Griffiths], western wheatgrass (Agropyron smithii Rydb.), needle-andthread (Stipa comata Trim. \& Rupr.), and threadleaf sedge (Carex filifolia Nutt.), 
interspersed with patches that had been planted to crested wheatgrass [Agropyron cristatum (L.) Gaertn.] in the 1930s (Uresk and Bjugstad 1995).

A total of 9 study sites were established in 2 grazing allotments that utilized different grazing strategies. The first allotment was comprised of 5 pastures. One pasture was predominantly crested wheatgrass that was always grazed from 1 May to 31 May (grazing after 15 October also was an option); it had 2 study sites. The other 4 pastures were native prairie that had since 1989 been under twice-over rotational grazing from 1 June to 15 October. Each of the 4 pastures had 1 study site. The second allotment was a single large pasture of predominantly native prairie with interspersed patches of crested wheatgrass. It was grazed season-long from 1 May to 15 September and had 2 study sites on native prairie plus 1 in a patch of crested wheatgrass. The 4 study sites within native rotational pastures were selected because the lessee had been using them for annual photographic monitoring purposes since 1989. The other 5 study sites were selected by Manske (1993) as typical representatives of their respective pastures. The native prairie rotational pastures comprised a total of 1,780 ha with a preference stocking rate of $0.872 \mathrm{AUM} \mathrm{ha}^{-1}$ and a 4.5-month grazing period. The seasonlong pasture was 8,500 ha with a preference stocking rate of $0.862 \mathrm{AUM} \mathrm{ha}^{-1}$ and a 4.5-month grazing period. The permitted stocking rate for all pastures was set by the US Forest Service at $100 \%$ of preference levels in 1993-1997, and at 90\% of preference levels in 1998.

\section{Sampling Procedures}

To support grasshopper density sampling via the method of Onsager and Henry (1977), each study site was provided with a set of 40 aluminum wire rings, each $0.1 \mathrm{~m}^{2}$, affixed for the duration of the study (1993-1998) in a 4x10 array with 8 $\mathrm{m}$ between rings. For the first 2 seasons of the study, Manske (1993, 1994b, 1994c) periodically determined percent basal cover, percent bare ground, and total above-ground biomass at all sites. Each site also was equipped with a $5.8-\mathrm{m}^{2} \mathrm{x}$ 1.2-m-high wire-mesh stock panel exclosure to protect an instrument shelter and weather monitoring equipment. In 1994 and 1998, Omnidata ${ }^{\circledR}$ Datapods were used to record daily minimum and maximum temperature at $5 \mathrm{~cm}$ below and 15 $\mathrm{cm}$ above the soil surface.

Grasshopper populations were sampled at varying intervals for 5 seasons,
1993-1995 and 1997-1998. Sampling began as soon as sites were accessible in the spring and terminated after killing frosts in the fall. Total density was estimated by counting grasshoppers within each ring of an array (i.e., in a total area of $4 \mathrm{~m}^{2}$ ), and a sweep net collection was taken along the perimeter of the array to establish composition of the population by species and by stage of development. Thereafter, an index of seasonal abundance called "grasshopper days" (GD) theoretically could be determined for any stage of any species at any site by calculating the area under a graph of density plotted as a function of time expressed in days (Hewitt and Onsager 1982). In practice, however, the sampling method is not reliable for very small grasshoppers, and during every season, some early-hatching species began development before the first sampling event. Therefore, GD values were calculated only for $3^{\text {rd }}$ instar or older stages. In concept, a GD differs from an AUM only in that the herbivores are smaller and the time units are shorter.

Study sites were sampled at 7-to 10-day intervals during 1993, 1995, and 1998, and at 2-to 3-day intervals during 1994 and 1997. That intensity of sampling supported estimation of certain stage-specific life history parameters for at least the more abundant species at all study sites. The parameters that were considered important in this study were average stage-specific survival rates for $3^{\text {rd }}, 4^{\text {th }}$, and $5^{\text {th }}$ nymphal instars, average development time per nymphal instar, average daily survival rate for both nymphs and adults, and the number of individuals that entered the adult stage. The mathematical procedure, which combined methods of Richards et al (1960), Kiritani and Nakasuji (1967), Manley (1976), and Onsager and Hewitt (1982a), was described in detail by Sanchez and Onsager (1988).

\section{Statistical Analyses}

Because of occasional instrument malfunction, the weather records from within grazing exclosures in 1994 and 1998, respectively, provided 5 and 3 natural time intervals that ranged from 11 to 38 days in duration when continuous data were available from each study site. For each of the 2 years, soil temperatures within each continuous time interval were converted to cumulative degree-days over $10^{\circ} \mathrm{C}$, the temperature used by Kemp and Sanchez (1987) as a threshold for modeling grasshopper egg development. Air temperatures were similarly converted to cumula- tive degree-days over $17.8^{\circ} \mathrm{C}$, a threshold for nymphal development (Putnam 1963). For each season, the degree-day data were subjected to an analysis of variance as a randomized complete block design with the 9 study sites handled as treatments and the intervals considered replications over time.

For routine exploratory analyses of grasshopper population or life history parameters, the basic statistical design was a $2 \times 2$ factorial of 4 grazing treatments comprised of 2 vegetation types, crested wheatgrass and native prairie, exposed to 2 methods of grazing, twice-over rotational and season-long. Each season was considered a replication in time. The treatment by season interaction was the error term. Data from different sites within the same treatment and year were considered subsamples. Treatment and error variances were partitioned into 3 orthogonal comparisons: (1) all crested wheatgrass sites vs all native prairie sites; (2) crested wheatgrass sites used for spring pasture in support of twice-over rotational grazing vs the crested wheatgrass site under seasonlong exposure to grazing; and (3) native prairie sites under twice-over rotational grazing vs native prairie sites under season-long grazing. The first comparison determined whether crested wheatgrass and native prairie habitats supported similar grasshopper population parameters. The second comparison assessed the effects of relatively heavy utilization by livestock early in the season at crested wheatgrass rotational sites (before turn-out on native prairie rotational sites) vs low to moderate utilization by livestock mostly later in the season at crested wheatgrass season-long sites (due to preference for native forage adjacent to the crested wheatgrass season-long site). The third comparison evaluated effects of a grazing strategy that rotated 8 distinct grazing periods over a series of 4 pastures in a different order each year vs traditional season-long grazing within a single pasture. The third comparison fulfilled the primary goal of this study.

In addition to the routine orthogonal analyses, graphs of all grasshopper life history or population parameters were examined for obvious departures from normal assumptions for the analysis of variance. Problems detected included unequal variances as well as treatment by season interactions. In such cases, the orthogonal analysis was considered misleading, and an appropriate alternative was developed and elaborated. 


\section{Results and Discussion}

\section{The Study Area}

Temperature and precipitation trends during the course of this study, based on weather records from Watford City, N.D., reported by the North Dakota Agricultural Weather Network (http://www.ext.nodak.edu/weather/ndawn), are illustrated in Figure 1. This study obviously was conducted during an interval of progressively warmer and dryer seasons. If the hypothesis of higher grasshopper densities in the presence of low precipitation and low forage production is true, then one would expect grasshopper populations to generally increase from 1993 to 1998 at all study sites.

The 1994 and 1998 weather data from within grazing exclosures revealed no significant differences among soil degree-days between sample sites during either year, or among air degree-days between sample sites during 1994. In 1998, air degree-days at the warmest site differed significantly ( $\mathrm{P}$ $=0.051)$ from the coolest site, but neither differed from any other site based on Duncan's multiple range test. The extreme sites were the 2 native prairie season-long sites, so that confirmed their credibility as a standard of comparison for possible effects of twice-over grazing. In other words, all sites had similar thermal potential to support grasshopper development, and there was no evidence of bias in site selection, at least with regard to factors like slope or aspect, which are known to influence soil and air temperatures. It should be emphasized that temperature data were obtained within grazing exclosures; therefore, there should be no major differences between grasshopper developmental parameters in comparable habitats (i.e., between crested wheatgrass sites or between native prairie sites) either in the absence of grazing or under identical grazing. If differences are then observed among grasshopper life processes that are driven primarily by tem-

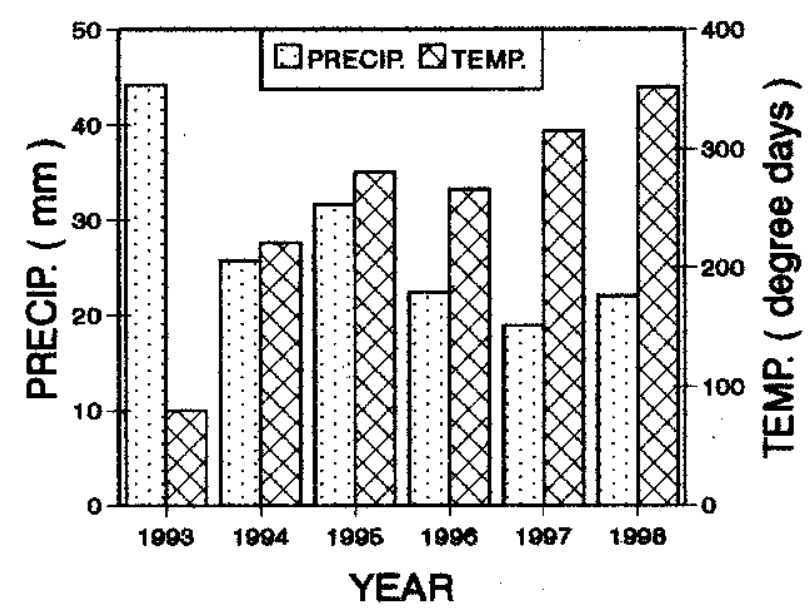

Fig. 1. Relationships between cumulative precipitation $(\mathrm{mm})$ and cumulative temperature (degree-days > 17.8 C) at Watford City, N.D., 1 Apr. through 31 Sept. 1993-1998, as reported by the North Dakota Agricultural Weather Network.

perature, it should be safe to assume that the grazing regimes differentially affected grasshopper microhabitat.

A summary of 1993 and 1994 cover and biomass estimates at the study sites published by Manske $(1993,1994 b, 1994 c)$ is given in Table 1 . All study sites had similar percent basal cover in 1993, but crested wheatgrass sites had less basal cover than native prairie sites in 1994. Slightly more bare ground was associated with seasonlong grazing than with rotational grazing at crested wheatgrass sites during both 1993 and 1994 and at native prairie sites in 1993 only. At crested wheatgrass sites, biomass was highest under season-long grazing because livestock tended to avoid eating crested wheatgrass when they had other alternatives. At native prairie sites, biomass tended to be slightly higher under rotational grazing, but stocking rates appeared to be conservative at all study sites, at least during the relatively cool and productive seasons of 1993 and 1994. In general, crested wheatgrass sites might be expected to support higher grasshopper densities than native prairie sites, because of more bare soil at crested wheatgrass season-long sites and less total canopy at crested wheatgrass rotational sites. However, site attributes in 1993 and 1994 did not suggest that any native prairie study site would be unusually prone to chronic or abnormal infestations of grasshoppers.

\section{Grasshopper Density Indexes}

Preliminary analyses of grasshopper density and phenology data indicated that marked changes in grasshopper days (GD) from season to season were multiplicative rather than additive. Therefore, all GD values were transformed to $\ln (\mathrm{X}+1)$ prior to final analysis. Retransformed grand means and significant P-values for all orthogonal comparisons are given in Table 2 , and selected retransformed seasonal means within the different grazing treatments are illustrated in Figure 2 and Figure 3.

Table 1. Percent basal cover, percent of soil surface not covered by vegetative canopy, and total above-ground plant biomass at grasshopper sampling sites on native prairie (NP) and crested wheatgrass (CW) habitats under twice-over rotational (R) vs season-long (S) grazing in the Little Missouri National Grasslands, McKenzie County, N.D., 1993 and 1994. ${ }^{1}$

\begin{tabular}{|c|c|c|c|c|c|c|c|c|}
\hline \multirow{2}{*}{$\begin{array}{l}\text { Habitat } \\
\text { type }\end{array}$} & \multirow{2}{*}{$\begin{array}{l}\text { Grazing } \\
\text { strategy }\end{array}$} & \multirow{2}{*}{$\begin{array}{l}\text { Grazing } \\
\text { season }\end{array}$} & \multicolumn{2}{|c|}{ Basal cover ${ }^{2}$} & \multicolumn{2}{|c|}{ Bare ground ${ }^{3}$} & \multicolumn{2}{|c|}{ Biomass $^{4}$} \\
\hline & & & 1993 & 1994 & 1993 & 1994 & 1993 & 1994 \\
\hline & & & \multicolumn{2}{|c|}{$(\%)$} & \multicolumn{2}{|c|}{$(\%)$} & \multicolumn{2}{|c|}{$\left(\mathrm{kg} \mathrm{ha}^{-1}\right)$} \\
\hline $\mathrm{CW}$ & $\mathrm{R}$ & 1 May - 31 May & 39.8 & 24.1 & $3.3-10.7$ & $2.6-3.9$ & $823-1187$ & $445-549$ \\
\hline NP & $\mathrm{R}$ & 1 Jun -15 Oct & 41.6 & 33.2 & $3.9-6.5$ & $3.5-4.8$ & $1004-1595$ & $980-1504$ \\
\hline NP & $\mathrm{S}$ & $1 \mathrm{May}-15 \mathrm{Sep}$ & 36.2 & 34.5 & $6.0-14.1$ & $3.6-5.5$ & 564-1225 & 839-1990 \\
\hline $\mathrm{CW}$ & $\mathrm{S}$ & $1 \mathrm{May}-15 \mathrm{Sep}$ & 36.0 & 26.1 & $0.9-17.3$ & $6.0-10.5$ & $1267-1491$ & $791-1363$ \\
\hline
\end{tabular}




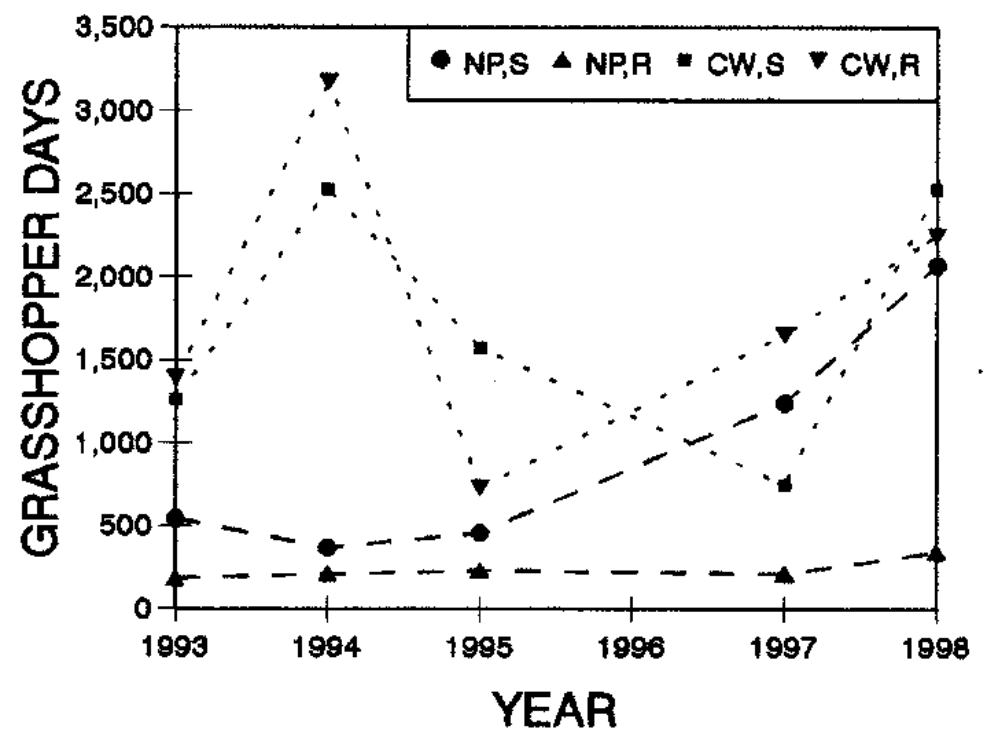

Fig. 2. Average cumulative grasshopper days $\left(3^{\text {rd }}\right.$ instar through adult stages $) \mathrm{m}^{-2}$ for all grasshopper species combined during each of 5 growing seasons in native prairie (NP) and crested wheatgrass $(\mathrm{CW})$ habitats under traditional season-long grazing (S; dotted lines) vs twice-over rotational grazing ( $R$; broken lines), 1993-1998.

The average grasshopper days (GD) for all grasshoppers $3^{\text {rd }}$ instar or larger encountered per site per grazing treatment per season is illustrated in Figure 2. Over the course of the study, the combined crested wheatgrass sites had significantly $(4.8 \mathrm{X})$ more GD than the combined native prairie sites, and the native prairie season-long sites had significantly (3.3X) more GD than the native prairie rotational sites (Table 2). It is noteworthy that the dramatic increases in GD that occurred in 1997 and 1998 at all crested wheatgrass sites and at native prairie season-long sites did not occur at native prairie rotational sites; that is, the local outbreaks did not occur under the twice-over system of rotational grazing.

These results encouraged further scrutiny of the grasshopper day (GD) data for evidence of beneficial or antagonistic effects of grazing treatments upon individual grasshopper species. Although more than 30 different grasshopper species were encountered over the course of the entire study, preliminary examinations of GD data for individual species revealed that 9 of them comprised the preponderance of infestations and thus may have contributed significantly to major differences between habitats and grazing strategies. The GD data for those species were subjected to individual analyses of variance. Again, grand treatment means for each species are given in Table 2. Seasonal means for species that contributed conspicuously to local outbreaks at native prairie seasonlong sites are illustrated in Figure 3. The species are ranked in Table 2 according to pasture, accounted for most of the increased grasshopper presence on crested differences between means.

*Indicated mean is significantly greater than its complement $\mathrm{P}<005$.

** Indicated mean is significantly greater than its complement $\mathrm{P}<001$. wheatgrass during the last 2 years of the study. A. deorum, as mentioned earlier, requires patches of bare soil for basking and for oviposition. It appears that none of the native prairie sites had enough bare ground (see Table 1) to support high populations of $A$. deorum.

The comparisons of grasshopper days within crested wheatgrass habitats (Comparison 2 of Table 2) essentially addressed the question of how individual species responded to differences in timing and intensity of defoliation. It was noted that 3 of the species that preferred crested wheatgrass over native prairie, $M$. san guinipes, M. infantiuis, and Melanoplus gladstoni Scudder, seemed to thrive equally well under early spring grazing or season-long grazing. Three other species, $A$. deorum, Trachyrhachys kiowa (Thomas), and Melanoplus femurrubrum (DeGeer), developed significantly higher densities under early spring grazing, while one, $P$. nebrascensis, did just the opposite. A. deo rum may have been prevented by high shading canopy from taking advantage of an abundance of bare soil at the crested wheatgrass season-long site (see Table 1), but otherwise, there was little evidence of a general influence of either canopy height or timing of defoliation within crested wheatgrass habitats. Rather, it appeared that grasshopper species somehow adjusted differentially to provide a similar overall density in crested wheatgrass habitats under either grazing regime.

In comparisons of grasshopper days within native prairie habitats (Comparison 3 of Table 2), no species was significantly more abundant at rotational sites than at season-long sites. However, 4 species were significantly more abundant at season-long sites than at rotational sites. In

Table 2. Mean cumulative grasshopper days per $\mathrm{m}^{2}$ during 5 growing seasons under twice-over rotational $(\mathbf{R})$ grazing vs traditional season-long $(\mathrm{S})$ grazing at native prairie $(\mathrm{NP})$ and crested wheatgrass $(C W)$ study sites, 1993-1998; and results of orthogonal statistical tests for significant

\begin{tabular}{|c|c|c|c|c|c|c|}
\hline \multirow[b]{2}{*}{ Species $^{1}$} & \multicolumn{2}{|c|}{ Comparison 1} & \multicolumn{2}{|c|}{ Comparison 2} & \multicolumn{2}{|c|}{ Comparison 3} \\
\hline & $\begin{array}{c}\text { All } \\
\text { CW }\end{array}$ & $\begin{array}{l}\text { All } \\
\text { NP }\end{array}$ & $\mathrm{CW}, \mathrm{R}$ & CW,S & $\mathrm{NP}, \mathrm{R}$ & $\mathrm{NP}, \mathrm{S}$ \\
\hline All species & $1619 * *$ & 340 & 1645 & 1569 & 229 & $748^{*}$ \\
\hline A. deorum & $31 * *$ & 2 & $88 * *$ & 4 & 2 & 2 \\
\hline M. infantiuis & $256^{* *}$ & 9 & 258 & 253 & 5 & $26^{*}$ \\
\hline M. sanglinipes & $455 * *$ & 81 & 415 & 547 & 78 & 87 \\
\hline T. kiowa & $51 * *$ & 4 & $98 * *$ & 14 & 3 & 6 \\
\hline M. femurrubrum & 14 & 7 & $35 * *$ & 2 & 9 & 5 \\
\hline o. obscura & 4 & $14^{* *}$ & 6 & 2 & 6 & $71 * *$ \\
\hline M. gladstoni & $53 *$ & 10 & 53 & 52 & 3 & $88 * *$ \\
\hline P. nebrascensis & $32 * *$ & 8 & 16 & $126 * *$ & 6 & 16 \\
\hline E. costalis & 10 & 18 & 9 & 11 & 10 & $57^{*}$ \\
\hline
\end{tabular}

Individual species are ranked according to order in which they appear during the season. 

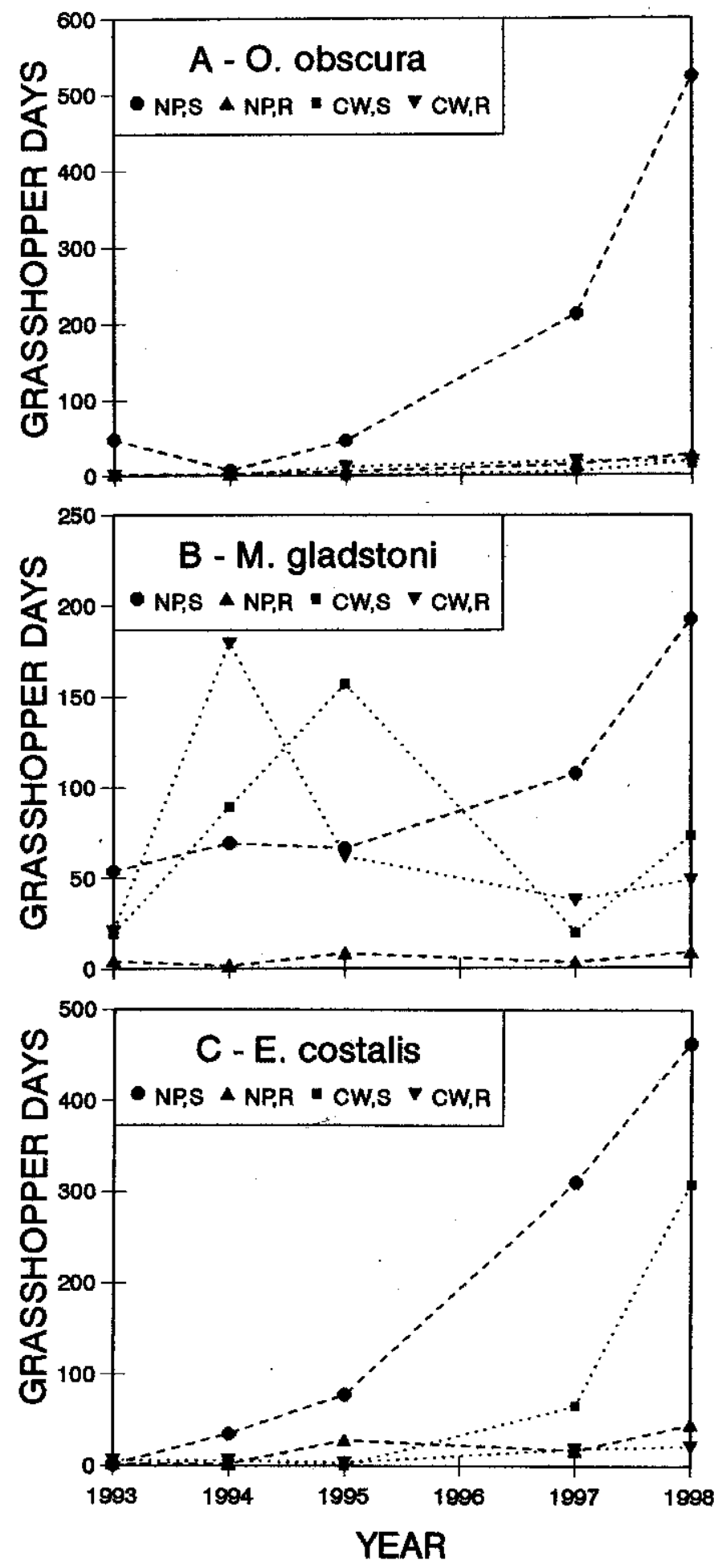

Fig. 3. Average cumulative grasshopper days $\left(3^{\text {rd }}\right.$ instar through adult stages $) \mathrm{m}^{-2}$ for 3 species that were highly responsive to grazing management during 5 growing seasons in native prairie (NP) and crested wheatgrass (CW) habitats under traditional season-long grazing (S; dotted lines) vs twice-over rotational grazing ( $R$; broken lines), 1993-1998.

the case of $M$. infantilis, all populations remained relatively low and were of little or no economic concern for the duration of the study. In contrast, 3 late-season species, Opeia obscura (Thomas), $M$. gladstoni, and Encoptolophus costalis Scudder, all increased dramatically at season-long sites during the hottest and driest years of the study, 1997 and 1998 (Fig. 3). All 3 were major contributors to the local outbreaks at season-long sites shown in Figure 2.

0 . obscura is a major pest species in shortgrass prairie, where its diet is 85 to $100 \%$ comprised of blue grama grass (Pfadt 1994). In the season-long study pasture, 0. obscura was common either where blue grama was the primary grass species or where an understory of blue grama was exposed for much of the growing season through removal of taller, cool-season grass canopy by grazing livestock. $M$. gladstoni is a polyphagous feeder that prefers forbs but tends to ingest plants in proportion to their abundance (Mulkern et al. 1962). In the season-long study pasture, it was most abundant in associations of 2 common food sources, blue grama grass and fringed sage (Artemisia frigida Willd.). E. costalis has been described as an omnivorous gramnivore (Mulkern et al. 1969) that occurs "in association with heavily grazed homogeneous grass areas" (Mulkern et al. 1964). 'It is not a major pest species on all rangeland (Dysart 1995), so its biology has not been studied intensively. In the season-long study pasture, it was the last species to complete nymphal development. During late summer and early autumn, nymphs were frequently observed to take shelter for the night in cracks in the soil.

The recurring theme of late development and adaptive behavior within a sparse canopy suggests that at least some grasshopper species typically participate in a race against weather in the northern Great Plains. This provides 2 plausible explanations for the relative scarcity of late-season species under twice-over rotational grazing. First, the blue grama understory is exposed for only relatively short intervals during and immediately after the 2 grazing events. That in itself may deter species that prefer or require short canopy and intense sunlight for thermoregulation (Willott and Hassall 1998). Second, if development of late-season species is significantly delayed (as occurs regularly with $M$. sanguinipes at rotational sites), the consequences to survival could be severe. If development is extended into periods of cool nights and only short midday intervals of temperatures above the developmental threshold, reproduction may become impossible.

\section{Grasshopper Density and Forage Consumption}

While grasshopper day values provide 
an accurate index of relative grasshopper presence, their relevance may be obscure until they are converted to more familiar units. A grasshopper day value can be converted to average density if average life span is known, and can be converted to forage consumption if a daily utilization rate is known. Such conversions are offered in Table 3 as a convenience to readers who may want to assess the practical value of observed differences between grazing strategies. Table 3 estimated density by assuming an average life span of 30 days per adult grasshopper, and estimated forage consumption by assigning average daily feeding rates reported by Hewitt and Onsager (1982) for small and medium-sized species of grasshoppers to the average grasshopper day values observed for $4^{\text {th }}$ and $5^{\text {th }}$ instar nymphs plus adults in this experiment. Because longevity tends to be inversely related to density (Onsager et al. 1981), the lowest densities in Table 3 probably were overestimated and the highest densities probably were underestimated. Nevertheless, an infestation as estimated at season-long sites in 1998 would be considered of outbreak proportion on any rangeland in western North America.

The estimates of forage consumption in Table 3 are considered about as accurate as allowed by current technology. If an AUM is defined as $364 \mathrm{~kg}$ of forage, it is noteworthy that estimated forage consumption by grasshoppers at native prairie season-long sites in 1997 reached $91 \%$ of the $0.862 \mathrm{AUM} \mathrm{ha}^{-1}$ that had been allocated for livestock. In 1998, in spite of the $10 \%$ reduction in stocking rate, forage consumption by grasshoppers at native prairie season-long sites reached $168 \%$ of the level allocated for livestock. In contrast, maximum consumption by grasshoppers at native prairie rotational sites was $26 \%$ of the livestock allocation in 1998.

\section{Grasshopper Life History Parameters}

Only 1 species, M. sanguinipes, was recorded on a regular basis at every site during every year of the study. Therefore, only $M$. sanguinipes provided sufficient data to support estimation of life history parameters within all 4 grazing treatments. Nevertheless, the parameters for $M$. san guinipes can provide important clues as to possible effects of grazing on other species as well. M. sanguinipes is the most serious grasshopper pest on rangeland in the United States (Dysart 1995). It occurs throughout most of North America and can develop economical infestations on
Table 3. Estimated density of grasshoppers and estimated forage consumed by $4^{\text {th }}$ and $5^{\text {th }}$ instar nymphs plus adults at native prairie sites under season-long vs rotational grazing in the Little Missouri National Grasslands, McKenzie County, N.D., 1993-1998.

\begin{tabular}{|c|c|c|c|c|c|c|}
\hline Parameter & Grazing strategy & 1993 & 1994 & 1995 & 1997 & 1998 \\
\hline Density & rotational & 2.6 & 1.4 & 3.3 & 2.1 & 5.6 \\
\hline (Adults $\mathrm{m}^{-2}$ ) & season-long & 8.3 & 4.6 & 6.2 & 18.4 & 26.8 \\
\hline Consumption & rotational & 37.0 & 21.9 & 55.8 & 32.6 & 73.6 \\
\hline$\left(\mathrm{Kg} \mathrm{ha}^{-1}\right)$ & season-long & 124.6 & 59.5 & 97.0 & 287.5 & 474.5 \\
\hline
\end{tabular}

range, pasture, and a variety of cultivated crops (Parker 1952). It consumes and apparently thrives on a wide array of both grasses and forbs (Mulkern 1967). It can have 2 generations per year in southern deserts and requires 2 years per generation in Alaska (Fisher 1994). In short, it can function more efficiently in more habitats than many other important economic species. Therefore, information on what is needed by $M$. sanguinipes in a given habitat may infer what is lacking for species that do not prosper there.

Certain anomalies in field data can preclude estimation of life history parameters (Onsager and Hewitt 1982a). For example, an occasional problem in this study was lower representation in a given instar than in a subsequent instar. Therefore, the number and type of parameters determined for individual sites were not constant. Interpretation of data also was complicated by a period of cold, wet weather from 29 June through 7 July of 1997, which interrupted the hatching of $M$. sanguinipes at 7 of the 9 study sites for an interval of 7 to 9 days. An advantage was that 2 distinct waves of hatchlings permitted estimation of 2 unique sets of nymphal developmental parameters at some sites within a single season. The disadvantage was that nearly all nymphs at the earliest site (a crested wheatgrass rotational site) hatched before the cold spell while all of the nymphs at the latest site (the crested wheatgrass season-long site) hatched after the cold spell.
Consequently, slow development and low survival of nymphs at the former site in contrast with fast development and normal survival of nymphs at the latter site affected experimental errors and increased the probability of a Type I error in any comparison that included a crested wheatgrass treatment. Therefore, only comparisons between native prairie treatments (i.e., comparison \#3 of the orthogonal set) were considered statistically valid. These are given in Table 4.

The Julian day associated with peak presence of various life stages is a useful index of grasshopper phenology (Kemp and Onsager 1986). The phenology of $M$. sanguinipes at $4^{\text {th }}$ peak instar was essentially identical for the 2 native prairie treatments (Table 4), and that conclusion was worthy of special emphasis. When subsequent parameters were found to differ significantly between native prairie sites, lack of phenological synchrony could be dismissed as a plausible cause. Equivalent development tended to occur earlier on the crested wheatgrass rotational sites, presumably because intensive forage removal began there about 4 weeks earlier and the grasshopper microhabitat warmed up faster than at any of the other sites. Equivalent development occurred later at the crested wheatgrass season-long site, presumably because livestock tended to avoid grazing crested wheatgrass out of preference for native forage.
Table 4. Life history parameters for Melanoplus sanguinipes as affected by twice-over rotational grazing vs traditional season-long grazing of native prairie in the Little Missouri National Grasslands, McKenzie County, N.D., 1993 to 1998.

\begin{tabular}{|c|c|c|c|c|}
\hline Parameter & $\mathrm{N}^{1}$ & \multicolumn{2}{|c|}{ Grazing strategy } & $\mathrm{P}$ \\
\hline Julian day for peak presence of $4^{\text {th }}$ instar nymphs & 6 & 204.3 & 204.1 & 0.89 \\
\hline $\begin{array}{l}\text { Stage-specific survival rate for nymphal instars 3-5 } \\
\text { Mean }\end{array}$ & $20,11^{2}$ & 0.512 & 0.662 & 0.06 \\
\hline Variance & & 0.027 & 0.073 & 0.03 \\
\hline Days for development per instar & 6 & 11.5 & 8.9 & 0.02 \\
\hline Average daily survival rate for nymphal instars $3-5$ & 6 & 0.94238 & 0.95418 & 0.53 \\
\hline Adults produced per square meter & 4 & 0.60 & 2.05 & 0.03 \\
\hline Average daily survival rate for adults & 5 & $0.99346^{3}$ & 0.97345 & 0.02 \\
\hline
\end{tabular}

number of broods for which parameter was estimated at least once per grazing strategy

2 total number of study sites at which parameter was estimated within rotational and season-long. strategies, respectively (see text for justification)

3 aberrant (see text for explanation). 


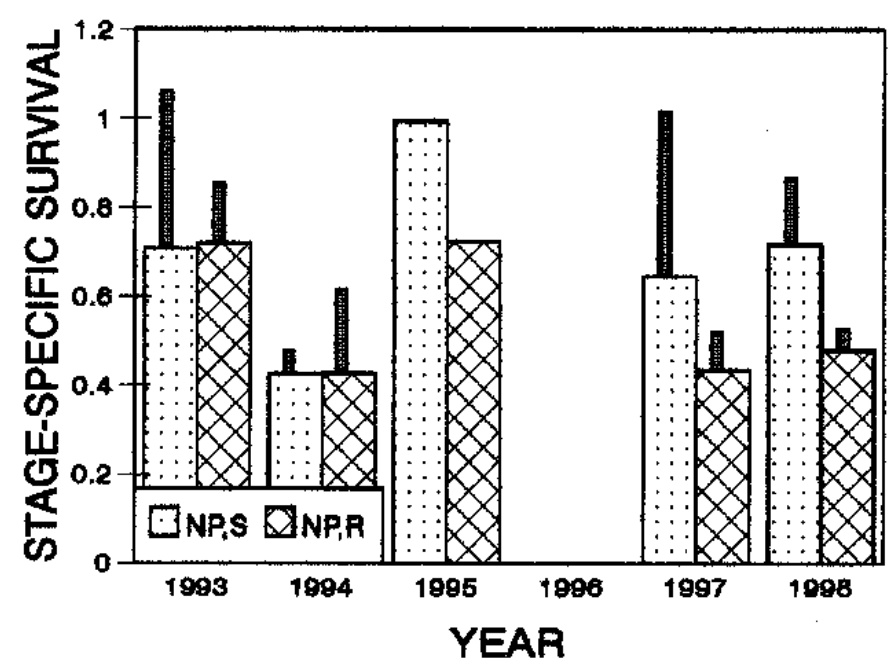

Fig. 4. Mean stage-specific survival rates for $3^{\text {rd }}, 4^{\text {th }}$, and $5^{\text {th }}$ instar nymphs of $M$. sanguinipes during 5 growing seasons between 1993 and 1998 on native prairie (NP), as affected by traditional season-long grazing (NP,S) vs twice-over rotational grazing $(\mathbf{N P}, \mathbf{R})$ (error bars indicate standard deviations).

Average stage-specific survival rates for $3^{\text {rd }}, 4^{\text {th }}$ and $5^{\text {th }}$ instar nymphs of $M$. san guinipes at native prairie study sites are given in Table 4 and Figure 4 . The routine orthogonal analysis indicated no difference between treatment means, but Figure 4 revealed a treatment by year interaction plus significantly greater variance within season-long sites than within rotational sites. The data were reanalyzed as a completely random design comprised of 2 treatments with unequal variances, and a P-value of 0.06 was obtained. That was considered justification to report lower and more stable stage-specific survival rates under rotational grazing than under season-long grazing. The observed individual stage-specific survival rates as well as the overall average rates were considered entirely realistic. They compare favorably with rates of 0.3993 to 0.8087 reported for natural populations of $M$. sanguinipes during different seasons at the same site near Roundup, Mont. (Onsager and Hewitt 1982a) and at different sites during the same season near Three Forks, Mont. (Sanchez and Onsager 1988). Stage-specific survival rates of 0.09 to 0.365 were reported for nymphs of 3 species, one of which was $M$. sanguinipes, in cage studies in the sand hills of Nebraska (Oedekoven and Joern 1998).

A stage-specific survival rate can be partitioned mathematically into an average daily survival rate (S) and days (d) required for development of a stage. Thus, stage-specific survival was defined to be (i.e., d was slightly lower) than or at rates similar to development of nymphs at
$\left(S^{d}\right)$, and $S=\left(S^{d}\right)^{1 / d}$. If any 2 parameters are known, the third can be calculated. There obviously is an infinite set of valu dhat will yield an ident partitioned to determine the range of $\mathrm{d}$ and S-values that occurred within each grazing treatment during the experiment..

Nymphs at all crested wheatgrass sites tended to develop either slightly faster observed stage-specific survival rate was native prairie season-long sites. At native prairie rotational sites, nymphs developed significantly slower than at native prairie season-long sites (Table 4). The average difference between treatment means (i.e., 2.6 days per instar), extended over 3 instars, would delay the appearance of adults under rotational grazing by an average of 7.8 days. That will be shown later to have a major impact on the proportion of nymphs that became adults. The averages, however, did not depict the full relationship observed in this study. While $d$ was relatively constant from year to year at the native prairie season-long sites, it decreased (i.e., the rate of development increased) significantly over the experimental period at the native prairie rotational sites (Fig. 5). During the coolest year of the study (1993), nymphs at native prairie rotational sites required about 14 days per instar, which was about 5.1 days longer per instar than at native prairie season-long sites. Logical hypotheses to explain these results are that ambient air temperatures within the canopy were cooler at native prairie rotational sites, or that nymphs were somehow deprived of opportunity for efficient thermoregulation at native prairie rotation sites [see Chappell and Whitman (1990) for a discussion of thermoregulation]. Either condition could have produced the observed results, either independently or in combination with the other. During the warmest years of the study (1997 and 1998), d was similar at all native prairie sites. A plausible explana-

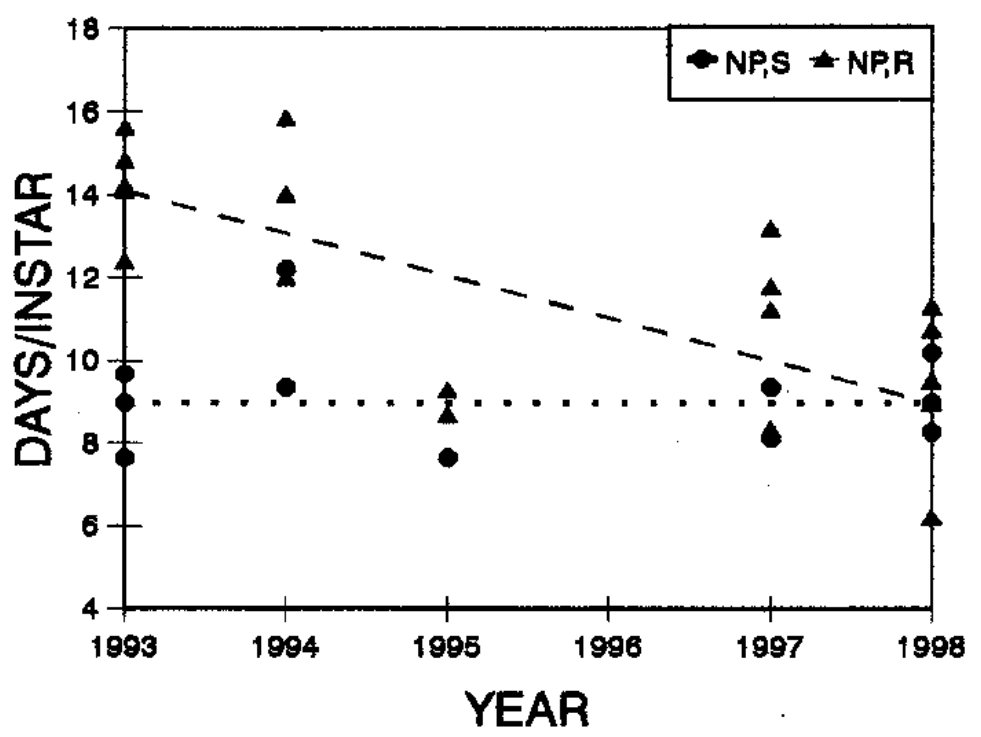

Fig. 5. Average number of days required by Melanoplus sanguinipes for development of $3^{\text {rd }}$, $4^{\text {th }}$, or $5^{\text {th }}$ instar stages during 5 growing seasons between 1993 and 1998 on native prairie (NP), as affected by traditional season-long grazing (NP,S; dotted line) vs twice-over rotational grazing (NP,R; broken line). 
tion is that nymphs at native prairie season-long sites may have invested considerable time in avoiding excessive body temperatures, the result of exceeding a thermal optimum, during the warmer later years, and therefore did not develop significantly faster than during the cooler earlier years.

While the average daily survival rate for nymphs $\left(S_{n}\right)$ tended to be slightly higher at crested wheatgrass sites than at native prairie sites, the tests for statistical significance were not considered reliable. In legitimate comparisons, $S_{n}$ did not differ significantly between grazing strategies at native prairie sites. However, a difference of the magnitude observed in Table 4 (i.e., a difference of 0.01180) can have major consequences if it operates over sufficient time. For example, when Sanchez and Onsager (1994) arbitrarily reduced estimated average daily survival rates of adults $\left(\mathrm{S}_{\mathrm{a}}\right)$ by 0.00428 and 0.00786 to adjust for the presence of parasitized females that were unable to produce eggs, the predicted rates of population increase were reduced by about $32 \%$ and $51 \%$, respectively, and they then agreed closely with observed rates. It also is critical to understand that an average daily mortality rate (i.e., $1-\mathrm{S}_{\mathrm{n}}$ ) would continue unabated during any period of extended development at native prairie rotational sites. If we assume that "normal" development requires 8.9 days for each of 3 instars as observed at native prairie season-long sites, then the fraction of $3^{\text {rd }}$-instar nymphs that survived to become adults at native prairie rotational sites can be estimated for 1993 as $\left.100\left(0.94238^{3(14-8.9}\right)\right)=40.3 \%$ of "normal", for the 5-year average of the study as $\left.100\left(0.94238^{3(11.5-8.9}\right)\right)=62.9 \%$ of "normal", but for 1998 as $100\left(0.94238^{3(8.9-8.9)}\right)=$ $100 \%$ of "normal".

Figure 6 illustrates some interesting and diametrical relationships between days per instar and survival rate (i.e., between d and $S_{n}$ ) at native prairie sites. Two of the data points in Figure 6 clearly were atypical. The 2 lowest $S_{n}$-values were excluded from this discussion because they are indicative of catastrophic conditions, they occurred among nymphs that had hatched before the cold, wet period in late June and early July of 1997, and they probably were induced by a local epizootic of pathogenic fungi as has been reported in other infestations (Onsager and Hewitt 1982a). Among the remaining data points in Figure 6, there was significant inverse correlation $(\mathrm{r}=-0.75, \mathrm{P}=0.038)$ between $\mathrm{d}$ and $\mathrm{S}_{\mathrm{n}}$, at native prairie season-long sites and significant direct correlation $(r=0.83$,

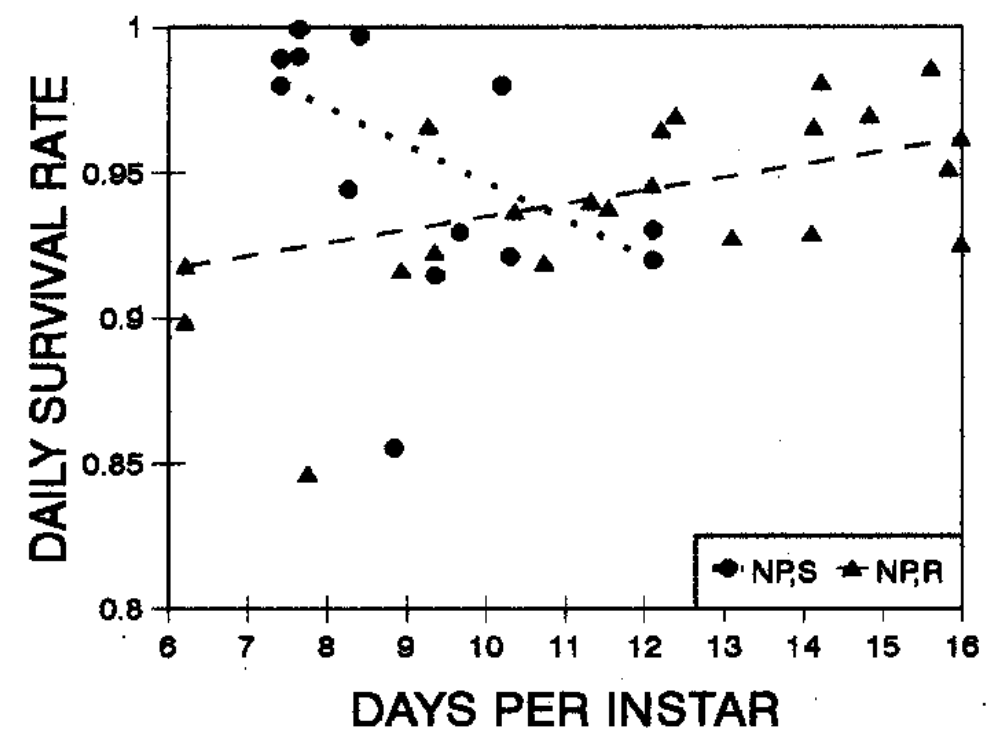

Fig. 6. Relationships between average daily survival rates vs average number of days required by Melanoplus sanguinipes for development of $3^{\text {rd }} 4^{\text {th }}$ or $5^{\text {th }}$ instar stages during 5 growing seasons on native prairie (NP), as affected by traditional season-long grazing (NP,S; dotted line) vs twice-over rotational grazing (NP,R; broken line) strategies.

$\mathrm{P}=0.012)$ at native prairie rotational sites. This paradox cannot be explained with the data at hand, but speculation clearly labeled as such is offered. Grant et al. (1993) suggested that $S_{n}$ may well be lower during seasons characterized by high rainfall and low sunshine, rather than by low temperature per se, because nymphs will be less active and more liable to predation. The current data obviously do not support that hypothesis. Figure 6 may be evidence of a bimodal response of daily survival rates to the heat-related factors that drive nymphal development. At the cooler extremes, conditions that extend nymphal development of $M$. sanguinipes to $15-16$ days per instar perhaps could inhibit activity or development of invertebrate predators that are inherently less adaptable than $M$. sanguinipes. At the warmer extremes, conditions that allow $M$. sanguinipes to complete a nymphal instar in only 7-8 days could perhaps allow nymphs to escape some predation by developing ahead of invertebrate predators to which they normally would be vulnerable. In any event, it is apparent in Figure 6 that all intermediate development times (i.e., on the order of 9-12 days per instar) were associated with similar nymphal survival rates, regardless of grazing treatment. Therefore, a worthwhile management objective would be to retain canopy characteristics that extend development to 13-16 days per instar. Even though the associated daily survival rates may be slightly higher than lowest possible rates, the extra time over which the higher rates operate will yield the lowest possible overall level of nymphal survival. The relative importance of the 2 parameters in this study is therefore under some conditions reversed from the order reported by Grant et al. (1993).

The mean estimated density of adult $M$. sanguinipes produced at native prairie rotational sites was significantly lower than (i.e., was only $29 \%$ of) the number produced at native prairie season-long sites (Table 4). Using the average nymphal parameters of Table 4, the model of Onsager (1983) estimated that the 2 average infestation levels could have risen from similar average densities of hatchlings (about 18.2 vs 16.5 hatchlings $\mathrm{m}^{-2}$, respectively). This is a classic example of the powerful impact that can be induced by forcing slightly reduced survival rates to function over slightly extended intervals of time.

The average daily survival rate for adults $\left(S_{a}\right)$ differed significantly between grazing treatments (Table 4$)$. The current average $S_{a}$. for native prairie season-long sites was markedly higher than in a study on mixedgrass prairie when $M$. san guinipes populations declined for 3 successive seasons (Onsager and Hewitt $1982 b)$. It was only slightly higher than in a 1-year study on crested wheatgrass where 2 populations almost replaced themselves (Sanchez and Onsager 1988). In Onsager's (1983) model, it was suggestive of a generation that is capable of 
approximately doubling in density. Therefore, the 5-year average $S_{a}$ for native prairie season-long sites in this study was entirely realistic. However, a 5-year average $S_{a}$ in excess of 0.99 , as reported for the native prairie rotational sites, is unprecedented and therefore considered biologically untenable. That value indicates the consistent presence of more adults than can be accounted for by presence of nymphs, and is clear evidence of consistent immigration of adult $M$. san guinipes into the native prairie rotational sites. Unfortunately, it is not possible to recapture either true values for $\mathrm{S}_{\mathrm{a}}$ or precise levels of immigration. However, if the observed densities of resident adults did indeed develop from similar densities of hatchlings, then immigrant adult females must have outnumbered resident adult females by about a $2.4: 1$ ratio at native prairie rotational sites in order to produce the required total number of eggs. At this point, lest someone question the wisdom of a grazing system that encourages immigration of grasshoppers, it should be pointed out that grasshoppers will leave areas with poor food resources and invade areas with good food resources. Therefore, if there is a choice, a ranch should strive to become a refuge for rather than a source of migrating grasshoppers.

\section{Conclusions}

These results agree with the earlier reports that associated high grasshopper populations with hot, dry weather in the Great Plains. They strongly suggest that grasshoppers could be responding primarily to levels of available heat (see Willott and Hassall 1998), which are affected by relationships between moisture levels and plant canopy density and which are modified by thermoregulatory behavior (see Willott 1997). That notion supports interesting speculation about future infestations at the study sites. Infestations in all crested wheatgrass habitats will likely remain high and variable regardless of future weather conditions or grazing strategy, with the species complex, especially $M$. san guinipes and $M$. infantilis, adjusting to take advantage of forage resources that are not utilized by livestock. If current drought intensity continues or increases, it is expected that permanent prime habitat for late-developing species within the native prairie season-long pasture could support total densities similar to or only slightly higher than densities observed in 1998. Under those weather conditions, however, a further increase in intermittent acceptable habitat would probably promote rapid and dramatic increases in overall numbers of at least E. costalis, O. obscura and M. glad stoni. In contrast, the low populations of those species at native prairie rotational sites would require perhaps 3-4 consecutive favorable seasons in order to increase to levels comparable to 1998 at native prairie season-long sites. In the event of continued drought, M. sanguinipes is the only species at native prairie rotational sites that could likely increase to outbreak levels within 2 seasons.

Concepts and technologies developed for grasshopper management in the northern Great Plains probably will not transfer directly to Palouse prairie, intermountain sagebrush, or shortgrass prairie ecosystems. In an 8-year study at a Palouse prairie site in western Montana, Belovsky and Slade (1995) reported that grasshopper density, survival, and reproduction responded directly in a density-dependent fashion to natural and experimental changes in availability of food. Annual changes in food abundance were associated with the annual variation in weather (rainfall and temperature), but most grasshopper generations produced more nymphs than the habitat could support, followed by accelerated mortality until grasshopper numbers matched the food supply. That mechanism would support the close relationship between long-term mean density and long-term carrying capacity reported for western Montana by Kemp and Dennis (1993). In a study of grasshopper density data and weather records over a 27-year period in the intermountain sagebrush ecoregion of southern Idaho, Fielding and Brusven (1990) reported that abundant winter precipitation and warm spring and summer temperatures were associated with high grasshopper populations, presumably through favorable effects on forage production. Similar studies on predominantly shortgrass prairie in Colorado and New Mexico (Capinera and Horton 1989) revealed that grasshoppers responded favorably to spring and summer moisture, which also would support abundant forage production. In a study on shortgrass prairie in Arizona, Nerney and Hamilton (1969) reported increased grasshopper populations after seasons with above-average winter and spring precipitation followed by abundant vegetative cover. Furthermore, both Fielding and Brusven (1995), in the intermountain ecoregion, and Capinera and Sechrist (1982), in the shortgrass prairie ecosystem, reported higher grasshopper densities at ungrazed sites than at grazed sites. These reports agreed that grasshopper densities were regulated by food abundance and increased to "outbreak" levels under above-average precipitation and above-average forage production. Fielding and Brusven (1996) suggested that such conditions may not cause undue competition between grasshoppers and livestock for available forage. Thus, prevention of such infestations may be unnecessary, undesirable, or impossible. (This does not deny the importance of severe infestations during normal seasons that follow unusually-productive seasons, or the importance of immigration of grasshoppers from rangeland to crops, but those problems are beyond the scope of this discussion.)

A grazing strategy that dampens fluctuation in grasshopper nymphal survival rates might also dampen fluctuation in density. According to the equalibrium parameters of Kemp and Dennis (1993), that could reduce the propensity for outbreaks in the northern Great Plains, especially if the grazing strategy tended to stabilize nymphal survival at a lower rate than otherwise expected. Twice-over rotational grazing appears to have reduced both the mean density and the carrying capacity of grasshoppers on native prairie. In general, both speculation and scientific evidence to date agree that twiceover rotational grazing has mitigated a localized grasshopper outbreak. Thus, grasshopper management through grazing management may be eminently practical in the northern Great Plains.

\section{Literature Cited}

Anderson, N.L. 1964. Some relationships between grasshoppers and vegetation. Ann. Entomol. Soc. Amer. 57:736-742.

Anderson, N.L. and E. Hastings. 1966. Some notes on rearing Aulocara elliotti (Orthoptera: Acrididae). Ann. Entomol. Soc. Amer. 59:718-719.

Beloysky, G.E. and J.B. Slade. 1995. Dynamics of two Montana grasshopper populations: relationships among weather, food abundance and intraspecific competition. Oecologia 101:383-393.

Biondini, M.E. and L.L. Manske. 1996. Grazing frequency and ecosystem processes in a northern mixed prairie, USA. Ecol. Appl. 6:239-256.

Campbell , J.B., W.H. Arnett, J.D. Lambley, O.K. Jantz, and H. Knutson. 1974. Grasshoppers (Acrididae) of the Flint Hills native tall grass prairie in Kansas. Kans. State Univ. Agr.. Exp. Sta. Res. Paper 19. Manhattan, Kans.

Capinera, J.L. and D.R. Horton. 1989. Geographic variation in effects of weather on grasshopper infestation. Environ. Entomol. 18:8-14. 
Capinera, J.L. and T.S. Sechrist. 1982. Grasshopper (Acrididae)-host plant associations: response of grasshopper populations to cattle grazing intensity. Can. Entomol. 114:1055-1062.

Chappell, M.A. and D.W. Whitman. 1990. Grasshopper thermoregulation, p.143-172. In: R.F. Chapman and A. Joern (eds.), Biology of Grasshoppers. John Wiley and Sons, New York.

Cushing, WJ., RN. Foster, K.C. Reuter, and D. Hirsch. 1995. Seasonal occurrence of common western North Dakota grasshoppers, p. VI.8-1 to VI.8-6. In: Integrated Pest Management User Handbook. USDA/APHIS Tech. Bull. 1809. Washington, D.C.

Dysart, R.J. 1995. Relative importance of rangeland grasshoppers in western North America: a numerical ranking from the literature, p VI.6-1 to VI.6-20. In: Integrated Pest Management User Handbook. USDA/APHIS Tech. Bull. 1809. Washington, D.C.

Fielding, D.J. and M.A. Brusven. 1990. Historical analysis of grasshopper (Orthoptera: Acrididae) population response to climate in southern Idaho. Environ. Entomol. 19:1786-1791.

Fielding, D.J. and M.A. Brusven. 1995. Grasshopper densities on grazed and ungrazed rangeland under drought conditions in southern Idaho. Great Basin Naturalist 55:352-358.

Fielding, D.J. and M.A. Brusven. 1996. Livestock grazing and grasshoppers: an interregional perspective. Univ. Ida. Coll. Agr. Bull. 785. Moscow, Ida.

Fisher, J.R. 1994. The effect of temperature on the post-diapause development and survival of embryos of three species of Melanoplus (Orthoptera: Acrididae). Ann. Ent. Soc. Amer. 87:604-608.

Grant, A., M. Hassall, and S. J. Willott. 1993. An alternative theory of grasshopper life cycles. OIKOS 66: 263-268.

Hewitt, G.B. and J.A. Onsager. 1982. A method for forecasting potential losses from grasshopper feeding on northern mixed prairie forages. J. Range Manage. 35:53-57.

Holmes, N.D., D.S. Smith, and A. Johnson. 1979. Effects of grazing by cattle on the abundance of grasshoppers on fescue grassland. J. Range Manage. 32:310-311.

Kemp, W.P. 1992. Temporal variation in rangeland grasshopper (Orthoptera: Acrididae) communities in the steppe region of Montana, USA. Can. Ent. 124:437-450.

Kemp. W.P. and M.M. Cigliano. 1994. Drought and rangeland grasshopper species diversity. Can. Ent. 126:1075-1092.

Kemp, W.P. and B. Dennis. 1993. Density dependence in rangeland grasshoppers (Orthoptera: Acrididae). Oecologia 96:1-8.

Kemp, W.P. and J.A. Onsager. 1986. Rangeland grasshoppers (Orthoptera: Acrididae): modeling phenology of natural populations of six species. Environ. Entornol. 15:924-930.

Kemp, W.P. and N.E. Sanchez. 1987. Differences in post-diapause thermal requirements for eggs of two rangeland grasshoppers. Can. Ent. 119:653-661.
Kiritani, K. and Y.F. Nakasuji. 1967. Estimation of the stage-specific survival rate in the insect population with overlapping stages. Res. Popul. Ecol. 9:143-152.

Manley, B.F.J. 1976. Extensions to Kiritani and Nakasuji's method for analysing insect stage-frequencydata. Res. Popul. Ecol. 17:191-199.

Manske, L.L. 1993. Modification of vegetation by grazing and mowing to affect grasshopper populations. p 81-89. In: USDA/APHIS Grasshopper Integrated Pest Management Project 1993 Ann. Rep. Boise, Ida.

Manske, L.L. 1994a. Ecological management of grasslands defoliation, p 130-160. In: F.K. Taha, Z. Abouguendia, and P.R. Horton (eds.), Managing Canadian rangelands for sustainability and profitability. Grazing and Pasture Tech. Program. Regina, Sask.

Manske, L.L. 1994b. Modification of native range vegetation by grazing management to affect grasshopper populations, $\mathrm{p}$ 99-108. In: USDA/APHIS Grasshopper Integrated Pest Manage. Project 1994 Ann. Rep. Boise, Ida.

Manske, L.L. 1994c. Modification of crested wheatgrass vegetation by grazing and mowing management to affect grasshopper populations, p 109-118. In: USDA/APHIS Grasshopper Integrated Pest Management Project 1994 Ann. Rep. Boise, Ida.

Mulkern, G.B. 1967. Food selection by grasshoppers. Annu. Rev. Entomol. 12:59-78.

Mulkern, G.B., J.F. Anderson, and M.A. Brusven. 1962. Biology and ecology of North Dakota grasshoppers, I. Food habits and preferences of grasshoppers associated with alfalfa fields. N. D. Agr. Exp. Sta. Res. Rep.7. Fargo, N. D.

Mulkern, G.B., D.R. Toczek, and M.A. Brusven. 1964. Biology and ecology of North Dakota grasshoppers, II. Food habits and preferences of grasshoppers associated with the sand hills prairie. N. D. Agr. Exp. Sta. Res. Rep 11. Fargo, N. D.

Mulkern, G.B., K.P. Pruess, H. Knutson, A.F. Hagen, J.B. Campbell, and J.D. Lambley. 1969. Food habits and preferences of grassland grasshoppers of the north central Great Plains. N. D. Agr. Exp. Sta. Bull. 481 Fargo, N.D.

Nerney, N.J. and A.G. Hamilton. 1969. Effects of rainfall on range forage and populations of grasshoppers, San Carlos Apache Reservation, Arizona. J. Econ. Entomol. 62:329-333.

Oedekoven, M.A. and A. Joern. 1998. Stagebased mortality of grassland grasshoppers (Acrididae) from wandering spider (Lycosidae) predation. Acta Oecologica 19:507-515.

Onsager, J.A. 1963. Characteristics of eggs and egg-pods of North Dakota Acndidae and studies of sites selected for oviposition. PhD Thesis. North Dakota State Univ. Fargo, N. D.

Onsager, J.A. 1983. Relationships between survival rate, density, population trends, and forage destruction by instars of grasshoppers (Orthoptera: Acrididae). Environ. Entomol. 12:1099-1102.
Onsager, J.A. 1995. The importance of grazing strategies to grasshopper management: an introduction, p V.1-i to V.1-3. In: Integrated Pest Management User Handbook. USDA/APHIS Tech. Bull. 1809. Washington, D.C.

Onsager, J.A. and J.E. Henry. 1977. A method for estimating the density of rangeland grasshoppers (Orthoptera: Acrididae) in experimental plots. Acrida: 6:231-237.

Onsager, J.A. and G.B. Hewitt. 1982a. Rangeland grasshoppers: average longevity and daily rate of mortality among six species in nature. Environ. Ent. 11:127-133.

Onsager, J.A. and G.B. Hewitt. 1982b. A method for forecasting potential losses from grasshopper feeding on northern mixed prairie forages. J. Range Manage.35:53-57.

Onsager, J.A., N.E. Rees, J.E. Henry, and R.N. Foster. 1981. Integration of bait formulations of Nosema locustae and carbaryl for control of rangeland grasshoppers. J. Econ. Entomol. 74:183-187.

Parker, J.A. 1952. Grasshoppers, p 595-604. In: Insects. USDA Yearbook of Agriculture. Government Printing Office, Washington, D.C.

Pepper, J.H. 1955. The ecological approach to management of insect populations. J. Econ. Entomol. 48:45 1-456.

Pfadt, R.E. 1994. Field guide to common western grasshoppers. Wyo. Agr. Exp. Sta. Bull. 912.

Pierson, F.B. and J.R. Wight. 1991. Variability of near-surface soil temperature on sagebrush rangeland. J. Range Manage. 44:491-497.

Putnam, L.G. 1963. The progress of nymphal development in pest grasshoppers (Acrididae) of western Canada. Can. Entomol. 95:1210-1216.

Richards, O.W., N. Waloff, and J.P. Spradbery. 1960. The measurement of mortality in an insect population in which recruitment and mortality widely overlap. Oikos 11:306-310.

Sanchez, N.E. and J.A. Onsager. 1988. Life history parameters in Melanoplus sanguinipes (F.) in two crested wheatgrass pastures. Can. Ent. 120:39-44.

Sanchez, N.E. and J.A. Onsager. 1994. Effects of dipterous parasitoids on reproduction of Melanoplus sanguinipes (Orthoptera: Acrididae). J Orth. Res. 3:65-68.

Smith, C.C. 1940. The effects of overgrazing and erosion upon the biota of the mixed grass prairie of Oklahoma. Ecol. 21:381-397.

Uresk, D.W. and A.J. Bjugstad. 1995. Herbage production, phenology, and soil moisture dynamics for plant communities in western North Dakota, p V.8-i to V.8-18. In: Integrated Pest Management User Handbook. USDA/APHIS Tech. Bull. 1809. Washington, D.C.

Willott, S.J. 1997. Thermoregulation in four species of British grasshoppers (Orthoptera: Acrididae). Functional Ecol. 11:705-713.

Willott, S.J. and M. Hassall. 1998. Life-history responses of British grasshoppers (Orthoptera:Acrididae) to temperature change. Functional Ecol. 12:232-241. 